\title{
DNA Replication Initiation Protein
}

National Cancer Institute

\section{Source}

National Cancer Institute. DNA Replication Initiation Protein. NCI Thesaurus. Code C95243.

A protein that is involved in the initiation of the DNA replication process. 